\title{
A REVIEW OF REPRODUCTION AND GAMETE MANAGEMENT IN THE AFRICAN CATFISH CLARIAS GARIEPINUS (BURCHELL)
}

\author{
VICTOR F. OLALEYE \\ Department of Zoology, Obafemi Awolowo University, Ile-Ife, Nigeria.
}

(Submitted: 16 February 2005; Accepted 16 May 2005)

\begin{abstract}
Information on the current status of reproduction and gamete management of the African Catfish, Clarias gariepinus (Burchell) a highly appreciated culturable fish species in Nigeria were reviewed. Natural and artificial reproductive behaviour as well as gonadal maturation rhythm in the highly fecund fish were documented. Various artificial reproductive techniques utilized for induced breeding in captivity and the attendant limitation were highlighted to facilitate understanding of the fish reproductive behaviour. In nature, $C$. gariepinus has a discontinuous reproductive cycle regulated by cyclically active gonad tropes. A gonadotropin surge trigger off by environmental cues usually facilitates spontaneous oocyte maturation, ovulation or spermiation. Under captive condition, the fish spawn easily with hormonal induction using either homoplastic pituitary gland suspension or synthetic hormonal preparations. The Nigerian clariid farming communities however prefer the use of homoplastic pituitary gland suspensions instead of synthetic hormonal preparations to induce spawning in fish farms because of the very expensive nature of the imported synthetic hormonal preparations.
\end{abstract}

Keywords: Catfish, gonad tropes, hormone, oocytes, oogenesis, Spermatogenesis, Claria gariepinus

\section{Introduction}

The clariid catfishes characterized by an elongated naked body with long dorsal and anal fins are one of the world's economically important group of fresh and brackish water fishes. In many countries, they form a significant part of inland fisheries. Primarily. the clariid freshwater fishes belonging to the Family Clariidae had a wide geographical distribution in Africa consisting of 14 genera (Teugels, 1986a) and 32 species (Teugels, 1986b). In Nigeria, Syndenham $(1980 ; 1981)$ reported the family consist of five subgenera namely: Clarias, Clarioides, Anguilloclarias, Platycephaceloides and Brevicephaloides.

The African catfish (Clarias gariepinus) (Syn. C. lazera $C \& V$ ) is the most studied and is of high significant importance to fisheries in Africa (Teugels, 1996). Recently however, Heterobranchus longifil is has successfully been introduced in aquaculture under identical conditions with promising results (Legendre et al., 1992). The most exciting feature of $C$. gariepinus is the high potential for high intensive culture without prerequisite for pond aeration or high water exchange (Hecht et al., 1988).

Clarias gariepinus has a unique suite of morphological, physiological, ecological and behavioural traits that equip it to succeed in freshwaters (Bruton, 1979a). The fish is hardy and adaptable to thrive in diverse environments with questionable water quality principally as a consequence of its air breathing ability (Hecht et al., 1996).C. gariepinus is a typically non-aggressive stalking predatory omnivore that hunts at night in turbid waters using non-visual primary sense organs especially, the senses of touch through the barbels and tactile organs on the mouth and skin (Bruton, 1996). The fish also exercise high trophic plasticity because it has ability to feed on wide array of natural preys under diverse conditions (Haylor, 1992).

Despite the potentials, its culture in Nigeria, $C$. gariepinus production is still unsophisticated. Production is basically at subsistence level farming with simple processing and marketing channels. Rarely is high-density culture practiced to meet either the domestic consumption demand or for export. Also there is the absence of a definitive clariid farming groups to facilitate cross-fertilization of ideas relating to the identified production problems.

Technologies for farming Clarias gariepinus have now been developed to varying degrees of sophistication. Hormonal preparations used successfully to induce spawning in the African catfish all over the world include Human Chorionic Gonadotropin (HCG); 11-deoxycorticosteroneacetate (DOCA); carp pituitary suspension, progestagen, pimozide and Hypothalamic Hormone Analogue (LH-Rha) (de Kimpe and Micha, 1974; Hogendoorn, 1977; Schoonbee et al. 1980; Hecht et al., 1982; Richter and van den Hurk, 1982; de Leeuw 
et al. 1985; and Richter et al., 1985). Hybrid cross between Clarias gariepinus and Heterobranchus longifilis has also been receiving considerable attention (Hecht and Lublinkhof, 1985; and Richter et al., 1985). Comparative studies between $C$. gariepinus and Heterobranchus longifilis and their reciprocal hybrids have also been reported (Legendre et al., 1992).

Unfortunately, local farmers have not translated the results of the research and development in Nigeria and elsewhere into practice. Farmers with smallholdings need to be convinced of the efficacy of a new technology as well as its cheapness before its adoption.Clariid farming community in Nigeria relies mainly on the use of homoplastic pituitary gland suspension than on synthetic hormonal preparations to induce spawnings in their fish farms. The use of carp or clariid pituitary suspension prepared freshly on the farm has been found to be cheap, practical and highly reliable compared to the expensive sophisticated synthetic hormone analogs. The objectives of the current exercise are to review the natural and artificial reproductive behaviour in $C$. gariepinus as well as to document the gonadal maturation rhythm. Various artificial reproductive techniques with their attendant limitations were also highlighted to facilitate better understanding of gamete management in the species.

\section{Reproductive Physiology of the African Catfish}

(a) Natural Reproductive Behaviour and Gonadal Maturation Rhythm

Rainy season is the primary reproductive period in C. gariepinus. Sexually matured individuals can be found all the year round in ponds, rivers, lakes and enclosures (Nwadukwe et al., 1983; Legendre, 1986) provided adequate and unrestricted feeding is available (Pham and Raguel, 1977; Richter et al., 1987a). Fecundity is relatively high in $C$. gariepinus ranging from about 30,000 to 100,000 eggs. $\mathrm{kg}^{-1}$ body weight (Balon, 1984a; Bruton, 1979). Ovaries present the same general morphology as in other teleosts (Balon, 1984b) with oviducts and the sperms being mono-flagellated (Legendre et al., 1996). The eggs with an adhesive attachment disk are generally small and fertilization is external (Bruton, 1979). C. gariepinus show altrical or continuum of alternative reproductive style (Bruton, 1989). The fish is an egg scatterer which awaits suitable environmental condition before spawning.

Gonadal maturation is associated with increasing water levels, temperature and photoperiod (Bruton, 1996). Spawning (which is preceded by massive aggregation of the fish), courtship and aggressive encounters between males occur on dark nights after the rains (Bruton, 1979). Pairings takes place between isolated individuals in shallow waters among inundated plants. The incubation period of the fertilized egg is short ( 24 hours) and the yolk absorption phase takes 2-4 days (Hecht et al. 1988).

In nature, the african catfish has a discontinuous reproductive cycle regulated by cyclically active gonadotropes (Peute et al., 1984). Under natural conditions, the annual breeding season of the species is limited to a few months (Bruton, 1979). Goos and Richter (1996) reported that both the ultrastructural appearance of the gonadotropes and the pituitary gonadotropin content showed cyclical changes in both sexes which parallel changes occurring in the reproductive cycle.

The internal gonadal rhythm for Clarias species has been shown to differ from region to region (Legendre et al., 1996). However, the common factor for spawning behaviour to commence is the onset of the rainy season and the accompanying flood regime. The spawning season starts February - June in Nigeria: between July and September in the Nile Delta (Egypt) and in the Ubanqui River (Central African Republic). Spawning period commences March-April in Lake Victoria (Uganda); December - February in Mazoe (Zimbabwe) and May-August in Hula Reserve (Israel) (Richter, 1976; van den Hurk et al., 1984;1985).

The annual reproductive cycle in the African catfish has been divided into the breeding phase, the resting period and the gonadal recrudescence phase (Peute et al., 1986; van den Hurk et al., 1984;1985). Accordingly, during the breeding period the gonad tropes are large and fully granulated with the pituitary gonadotropin content reaching the maximum level. During the same period, gametogenesis comes to an end and the gonadotropin surge, which takes place at least once lead to oocyte maturation, ovulation or spermiation.

In Nigeria, the resting period occurs in September and February. During the period, an increasing number of fusion products of secretory granules and globules occur in the gonad tropes. Peute et al. (1986) associated the increased number of granules and globules to breakdown of stored hormones. Appearance of residual bodies, cell shrinkage and a considerable drop in the pituitary gonadotropin content characterise the late resting period (van den Hurk et al., 1984) and gametogenesis remain absent (van den Hurk et al., 1985). Gonadal recrudescence with full gametogenesis and restoration of sex steroid synthesis and redeveloping of the gonad tropes in the fish in Nigeria occur March and April (Nwadukwe et al., 1983). The gonadal recrudescence phase is characterised by increase in the gonadal size, granulation and augmentation of the hypophysial gonadotropin content.

Gonadal functions are regulated by gonadotropic hormones (GTH) produced by the pituitary gland 
(Goos et al., 1986). The secretion of gonadotrophic hormones is regulated by neurohormones mainly of hypothalamic origin and by the gonadal hormones (Koide et al., 1992). Consequently cells producing GTH play a central role in the control of reproduction (Nozaki et al., 1990). Studies have shown that when the african catfish reach maturity under favourable conditions of adequate food supply, the female catfish undergo constant production and storage of gonadotropin (Goetz, 1983). Also, the fish pituitary system through a negative feedback action on the hypophysial gonadotropin secretion ensures a continuous but limited release of this hormone sufficient only for production and maintenance of postvitellogenic oocyte but not enough for spontaneous oocyte maturation, ovulation or spermiation.

In nature the prespawning gonadotropin surge is induced by environmental factors such as increase water level and flooding of marginal areas (Bruton, 1979). The environmental cue ensures increase in hypophysial gonadotropin secretion through a positive feedback action of the gonadal steroids to induce the hypothalamus-pituitary system to reach higher activity levels. Goos and Richter (1996) reported that the gonadotropin surge induces the conversion of $17 \alpha$ OH-progesterone into $17 \alpha$ hydroxy-20- $\beta$ dihydroprogesterone which is the final maturation inducing substance in C. gariepinus. In the absence of gonadotropin surge, the event behind the process that lead to oocyte maturation, ovulation or spermiation does not occur (Jalabert, 1976; Goetz, 1983).

\section{(b) Gonadal Maturation Rhythm in Captivity}

The african catfish grows and reaches sexual maturity in captivity within 6-9 months of age. However there is generally no spontaneous reproduction under culture conditions. In most cases, gametogenesis is completed, postvitellogenic eggs and ripe sperm cells are presented. Although oogenesis and spermatogenesis have been reported to be normal in C. gariepinus under culture, the final oocyte maturation, ovulation or spermiation do not occur because the environmental cues that trigger the gonadotropin surge are difficult to identify or mimic on the farm. Goos and Richter (1996) reported that the absence of an environmental cue in combination with unavoidable stress cause a blockage of the gonadotropin releasing hormone $(\mathrm{GnRH})$ and consequently gonadotropin surge release fail to occur. The authors also reported that $\mathrm{GnRH}$ blockage in the fish is effectively enforced by hypothalamic dopaminergic inhibition and identified the sex steroids that play a role in the negative feedback control of gonadotropin release. The identified sex steroids, which were found to interact with hypothalamic dopamine metabolism to cause the inhibition were 11-keto-testosterone, and testosterone.

The african catfish raised in captivity and constantly kept under favourable husbandry conditions throughout the year have pituitaries containing large and densely granulated gonadotropes (Peute $e t$ al., 1984) storing large amount of gonadotropin (de Leeuw et al., 1985). Such fish show a continuous cycle with numerous ripe sperm cells and postvitellogenic oocytes at all seasons (Richter and van den Hurk, 1982) but without spontaneous spermiation, ovulation and maturation. The absence of a discontinuity in the annual reproductive cycle of the fish primarily results from the absence of a prespawning gonadotropin surge and a postspawning regression of the gonadotropes (Richter et al., 1987b). The failure to release large amount of gonadotropin has been found related not to insufficient storage of the hormones in the gonadotrophic cells (de Leeuw et al., 1985) but rather to the hypothalamic dopaminergic inhibition which prevented the release of $\mathrm{GnRH}$ in the fish and/or prevention of the hormone from eliciting the desired effects (Goos and Richter, 1996). Also the involvement of extracellular $\mathrm{Ca}^{2+}$ seem to be obligatory for the $\mathrm{GnRH}$ induced GTH release. Van Asselt et al. (1989) reported that the GnRH stimulation of GTH release was strongly inhibited in the absence of $\mathrm{Ca}^{2+}$ or in the presence of the $\mathrm{Ca}^{2+} \mathrm{x}$ -channel blocker (Nifedipine).

\section{Reproductive Techniques}

(a) Gamete Biology, Pheromonal Induced Ovulation, Spermiation and Spawning

The study of gamete biology of the clariid species, which is still at a nascent stage in Nigeria, precludes the optimization of gamete management and manipulation techniques for successful natural and artificial reproduction in C. gariepinus. Studies have shown that simple endocrinological methods can be used to evoke oocyte maturation, ovulation or spermiation to meet both scientific and practical applications on the farms. Goos and Richter (1996) reported that african catfish reared from egg to maturity in the laboratory under similar feeding and temperature condition with different photoperiodic regimes showed an uninterrupted ovarian activity with postvitellogenic oocyte at all seasons. According to them such fish could be induced all year round to produce large quantities of viable eggs. Matured African catfish brought from the natural habitat to an indoor hatchery under conditions of opitmal food supply, constant water temperature (about $25^{\circ} \mathrm{C}$ ) and normal local changes in day length makes the period of successful artificial propagation to increase from 10 to 11 months a year. 
Old broodstock are preferable for reliable spawning. Good African catfish broodstock care entails maintenance of appropriate standing crop weight with density not exceeding $1300 \mathrm{~kg} . \mathrm{ha}^{-1}$ (Legendre, 1986) and the provision of adequate food supply usually in form of supplemented pelleted feed. Under hatchery conditions, good quality eggs and sperms can be obtained continuously in $C$. gariepinus when the water temperature is constantly maintained at $25^{\circ} \mathrm{C}$ (Richter et al., 1987a). Good broodstock can be stripped every 6-8 weeks (Hogendoorn and Vismans, 1980). However, temperature plays a very vital role in achieving optimum pre-spawning conditions. Richter et al. (1982) observed that at $30{ }^{\circ} \mathrm{C}$ the proportion of atretic oocytes increased and the testis regressed.

The African catfish do not spawn individually but in groups. During the period of spawning, pheromonal interaction between females is an important process to synchronise the spawning process. Several studies have shown that the absence of spontaneous spawning in $C$. gariepinus kept under husbandry conditions is caused by shortage of suitable pheromones eliciting spawning behaviour, gonadotropin release, oocyte maturation and ovulation (Stacey et al., 1986; Schoonen and Lambert, 1986; Schoonen et al., 1987a, b, c).

Steroid conjugates have been shown to act as pheromones (Resink et al., 1987). Female fish exposed to ovarian fluid of ovulated females also has an increased plasma GTH levels (Resink et al., 1989a). A combination of male and female pheromones administered as a replacement of the ovulated female also instigated ovulation responses. Resink et al. (1989b) also reported that ovulation could be induced when female fish were held in the presence of a male and tactile stimuli were avoided. However, the authors reported such responses were limited to natural breeding periods only. $C$. gariepinus has also been induced to spawn naturally and successfully when ripe fish were placed in freshly filled ponds that has been dried for a time (De Kimpe and Micha, 1974; van der Waal, 1974). However, the number of fingerlings thus obtained is generally very poor (Goos and Richter, 1996).

\section{(b) Hormonal Induced Ovulation, Spermiation and} Maturation

Studies have shown that stepwise control of reproduction in $C$. gariepinus allow gamete preservation and manipulation under husbandry conditions. Presently, hormonal inducement and artificial fertilization are attracting much attention in terms of research and its applicability in farm situations as they allow for greater control over various steps in the fish reproductive cycle. Many techniques using hormonal-induced ovulation and artificial insemination to ensure spawning an: fertilization of the african catfish in captivity has: been perfected. The exogenous hormone sources commonly adopted either stimulate hypophysation or the gonadotropic hormone or artificially induce hypothalamic hormone discharges (Legendre et al.. 1996).

Gonadotropin is central to $C$. gariepinus reproductive processes. The regulation of the release of the hormone from the gonadotrophic cells in the pituitar. is very important. Oocyte maturation and ovulation are induced by administering exogenous gonadotropin (Eding et al., 1982). Under farm condition, injection of a crude homogenate of catfish pituitaries forms a simple and reliable method to induce ovulation in $C$. gariepinus| (Hogendoorn and Vismans, 1980). In most farm holdings in Nigeria, whole pituitaries are removed from sexually matured adult male African catfish during spawning season and are either used immediately or stored in absolute ethanol or acetone (Nwadukwe et al., 1983). During application, the pituitaries are simply homogenised in sterile water or in most cases on the farm applications uncontaminated rainwater is used. The homogenate obtained is then injected into females where it elicits the required response.

Pituitary gonadotropin induces oocyte maturation and ovulation indirectly by stimulating synthesis of maturational steroids in the ovarian follicles (Goetz, 1983). Studies have however shown that ovulation induction is of no avail when the ovaries do not contain numerous postvitellogenic oocytes (Richter $e t$ al., 1987a). The implication is that artificial propagation can be applied successfully under natural conditions only during the breeding period or at the beginning of the resting period.

Hormonal preparations which have been tested for artificially-induced breeding of African catfish female broodstock and the various limitations include:

(i) Clarias pituitary extract (Van der Waal, 1974; Micha, 1976; Schoonbee et al., 1980; Hecht et al., 1982). The limitation of using the Clarias extract is that fish must be sacrificed to get at the pituitary gland. Also, the dose must be calculated on a donor: recipient weight basis.

(ii) 11-deoxycorticosterone-acetate (DOCA) (De Kimpe and Micha, 1974; Pham and Raugel, 1977; Hogendoorn, 1979). The artificial hormone is limited by the fact that the steroid could only induce oocyte maturation only and not ovulation (Richter and Van den Hurk, 1982). However, stripping of eggs could be possible after DOCA treatment as ovulation could only be evoked mechanically. Also infections under the skin (which follow intramuscular injections) have been reported. 
$=\quad 17 \alpha$-hydroxyprogesterone successfully induces both oocyte maturation and ovulation (Richter et al., 1985). Two successive injections are however required with time interval of $4 \mathrm{hr}$ to achieve the required result.

in Carp pituitary extract (Hogendoorn, 1979; Hogendoorn and Vismans, 1980; Richter and van den Hurk, 1982). Using the extract involves sacrificing the fish.

$\checkmark$ Human Chorionic Gonadotropin (HCG) alone (Eding et al., 1982). The limitation to its usage is the cost.

vi) HCG + Carp pituitary extract (Shoonbee $e t$ al., 1980). The limitation of the usage of the combination of the two hormones is the cost.

vii) Hypothalamic hormone analogue (LHRHa) (de Leeuw et al., 1985a). The hormone analogue is efficient in inducing oocyte maturation and ovulation but its potency is increased when administered with pimozide.

ivii) Hypothalamic hormone analogue (LHRHa) with antidopamine antagonist (Goos et al., 1987). The limitation to its use is the cost.

(ix) hormonal-induced ovulation and spontaneous oviposition and fertilization by male in culture media (semi-natural spawning). The method is unreliable for $C$. gariepinus fingerling production due to heavy losses of eggs and fry (Hogendoorn, 1979).

(c) Hormonal Dosage and Gamete Management Close monitoring of the optimal hormone and hormone dosage essential for inducing oocyte maturation is essential for proper gamete preservation and management. The recommended dose of Clarias pituitary to be administered to the female broodstock is calculated on a 1.5:I (donor: recipient) ratio. Such induced females with suitably developed eggs can usually be stripped 12 hours after receiving a single dose at a temperature of $28{ }^{\circ} \mathrm{C}$ or 20 hours at a temperature of $22^{\circ} \mathrm{C}$ (Legendre et al. 1996). Owing to high levels of aggression, the injected broodstock females are usually separated from each other in holding tanks by sturdy screens. Ovulation is not synchronous in individual female broodstock and is usually affected by the exogenous hormonal application. After hCG injection for example, ovulation takes $7-11$ hours at $30^{\circ} \mathrm{C}$ in C. gariepinus (Legendre and Otéme, 1995).

Factors and mechanism governing ova survivability in vivo are poorly understood. It is pertinent to note however that survival time during which ova are able to develop are normally very short and temperature dependent. The phenomenon of ageing that leads to over-ripening of ova maintained within ovaries occur rapidly. Survival time measured by hatching percentage is estimated by the time lapse between ovulation and the moment at which the initial egg fertilisability begins to drop. The correct time of stripping therefore becomes increasingly critical at higher temperatures (Hogendoorn and Vismans, 1980; Espinach Ros et al., 1984). After successful hormonal induction of ovulation in C. gariepinus with carp pituitary suspension at the rate of $4 \mathrm{mg} \cdot \mathrm{kg}^{-1}$, Hogendoorn and Vismans (1980) reported that the ova survival time was about 9 hours at $20^{\circ} \mathrm{C}$ while the survival time reduced to 2 hours at $30^{\circ} \mathrm{C}$. Unlike in the females, the volume of sperm collected after hormonal stimulation (induced spermiation) is generally low no matter the time lag (van der Waal, 1985).

\section{(d) Artificial Insemination and Fertilization}

Holding the female broodstock in a head-up vertical position tests readiness of the eggs for fertilization. The eggs begin to run freely from the genital pore when the fish is ready to be fertilized. Stripping $C$. gariepinus females as soon as free-running ova (referred to as unriped ova) could be obtained immediately after carp pituitary suspension treatment without waiting for the post-ovulatory maturation period led to low hatching percentages (Richter and van den Hurk, 1982) and high proportion of deformed larvae after fertilization (Hogendoorn and Vismans, 1980). In a later study, the first free-running eggs were found by Legendre and Ótémé (1995) to be of good quality with high hatching rates and low proportion of deformed larvae. Ova post-ovulating maturation period is dependent on temperature. Richter and van den Hurk (1982) reported that the best results were obtained about 10,3, and 1 hours after pituitary suspension treatment at $20^{\circ} \mathrm{C}, 25^{\circ} \mathrm{C}$ and $30^{\circ} \mathrm{C}$ respectively. Waiting the mandatory postovulatory maturation period also ensures that the eggs could be stripped more easily than before (Legendre and Ótémé, 1995).

The time lapse during which fertilization of ovulated oocytes remain possible after being emitted by the female or exposed soon after stripping to water or various solution is referred to as ova viability. In the african catfish the egg viability is very short (van den Hurk, 1982). The attendant loss of fertility after the mandatory time lapse was probably due to the closing of the micropile resulting from expansion of the ova envelopes (Legendre et al., 1996). The eggs are also heat labile with thermal tolerance limits between $22{ }^{\circ} \mathrm{C}$ and $35^{\circ} \mathrm{C}$ (Legendre and Teugels, 1991). A temperature of $30^{\circ} \mathrm{C}$ was however considered optimal for egg incubation (Mollah and Tan, 1982; Haylor and Mollah, 1995).

C. gariepinus is oligospermic (GSI < $1 \%$ ) (Legendre et al., 1996) and the spermatozoa may be present in the testis all year round although their viability cannot 
be ascertained. Semen is easily collected from males injected with Clarias pituitary homogenate unlike in the untreated fish (van der Waal, 1985). In case of insufficient sperm availability males are sacrificed and the milt is extracted from the testis cut into small pieces extended in a saline solution or pressed through a net fabric into the egg (Hogendoorn and Vismans, 1980; Mollah and Tan, 1983; Legendre, 1986). The fertilizing capacity of the intratesticular sperm is maintained when inactivated in $155 \mathrm{mM} \mathrm{NaCl}$ solution (dilution 1: 10 or 1:100) (Hogendoorn and Vismans, 1980). In vitro sperm storage in non-diluted state after sampling for 24 hours usually at $4-5{ }^{\circ} \mathrm{C}$ reduces the fertilizing capacity of spermatozoa by about $4 \%$ (Legendre, 1986).

Ova generally survive only a few hours after ovulation and as such fertilization must be carried out soon after (Legendre et al., 1996). Genetic variability in the hatchlings is increased when a minimum of two males are used to fertilize batches of eggs. Fertilization is best effected by first diluting the sperm in physiological saline after which the solution is mixed with the eggs. After the stripping of the female broodstock, $200 \mathrm{ml}$ of eggs and $3 \mathrm{ml}$ of sperm are mixed together in a bowl to which $100 \mathrm{ml}$ of activating solution (17 $\mathrm{mM} \mathrm{NaCl} ; 5 \mathrm{mM}$ Tris; $\mathrm{pH} 8$ ) is added (Haylor, 1983). 3 g.t-1 $\mathrm{NaCl}$ solution could also be used as activating solution for the fertilization process (Horvath and Tamas, 1976). After 2-5 minutes of gentle stirring, the eggs are transferred to an incubator. The time of contact between sperm and ova for fertilization to occur is about 1 minute (Hogendoorn and Vismans, 1980; Legendre, 1986).

The African catfish produce mostly independent sticky eggs spread in a single layer or stuck on vegetable materials in spawning nests in case of natural spawning. After fertilization, the fertilized eggs become sticky on contact with water. In the hatchery, the fertilized eggs are spread in a single layer on a horizontal $1 \mathrm{~mm}$ material mesh to which they adhere rapidly (Haylor, 1993). In Nigeria where there are very few sophisticated hatcheries, the fish farmers commonly use mosquito nets and cacabans as substrate. The fertilized eggs are spread in a single layer on the substrate to which the sticky fertilized eggs adhere. The material with the attached eggs is then suspended slightly off the vertical axis in hatching troughs containing well-aerated water. The development time during the incubation period is temperature dependent. Once hatching occurs, the new hatchlings simply fall to the bottom of the hatching troughs while the egg envelope remain adhered to the screen material. The larvae are then easily separated from the unfertilized egg and egg shells by farmers by simply lifting the cacaban or the screen net.

\section{Conclusion}

C. gariepinus is highly relished as food fish in Nigeria because of its excellent meat quality. Apart from being highly priced for its food value, the potential for high intensive culture of the species makes the fish to be preferable to any other culturable species. $C$. gariepinus is known to have an excellent food conversion apart from its trophic plasticity in captivity (Haylor, 1992). The fish is also resistant to diseases (Hecht et al., 1988) and has relatively low requirement for water quality (Teugels, 1996). It is also very highly fecund and has ability to spawn under captive conditions (de Leeuw et al., 1985). Ensuring sustainable production of such priced species entails proper broodstock management with hormonal injection using either homoplastic pituitary gland suspension or synthetic hormonal preparations to enhance propagation and continual recruitment into both the wild and the cultured populations.

Most catfish farms in Nigeria however depend on broodstocks collected from the wild populations with attendant inherent inbreeding problems. Most of the time, C. gariepinus broodstocks from the wild produce fingerlings with decreased fitness noticeable after only a few generations. Successful catfish farming operations require the local fish farmer to observe requisite protocols, which is a sine qua non for successful reproduction and gamete management in the species. Such important protocols for broodstock management include those on the nutritional requirements, optimal environmental conditions and feeding practices. Currently the problems appear insurmountable because the extension workers who are supposed to be in-charge of the on-the-farm training are poorly remunerated and badly motivated. Also, without Government subsidy, most of the imported farm inputs and technologies will forever be beyond the reach of the average Nigerian African catfish farmer.

\section{REFERENCES}

Balon E.K.. 1984a. Patterns in the evolution of reproductive styles in fishes. In G.N. Potts and R.J. Wootton (editors) Fish Reproduction: Strategies and Tactics. Academic Press London, pp. 35-53.

Balon E.K., 1984b. Reflections on some decisive events in the early life of fishes. Trans. Amer. Fish. Soc. /13, 178185.

Bruton, M.N., 1979. The breeding biology and early development of Clariasgariepinus (Pisces: Clariidae) in Lake Sibaya, South Africa with a review of breeding in species of the subgenus Clarias. Trans. Zoo. Soc. Lond. 35. 1-45.

Bruton, M.N., 1989. The ecological significance of alternative life-history styles. In: M.N. Bruton (editor), Alternative Life-History Styles of Animals. Perspectives in Vertebrate Science. Kluwer Academic Publishers, Dordrecht, pp. 503-533.

Bruton, M.N. 1996. Alternative life-history strategies of catfishes. In: Legendre, M. and J-P. Proteau (eds). 
The Biology and Culture of Catfishes. Aquat. Living Res., Paris, 9 Hors. Series, pp. 35-4l.

de Kimpe, P. and Micha, J.C., 1974. First guidelines for the culture of Clarias lazera in Central Africa. Aquaculture 4, 227-248.

de Leeuw, R., Resink. J.W., Rooyakkers. E.J.M. and Goos H.J.Th., 1985a. Pimozide modulates the luteinizing hormone-releasing hormone effect on gonadotropin release in the african catfish, Clarias lazera. Gen. Comp. Endocrinol. 58, 120-127.

Eding. E.H., Janssen, J.A.L.. Kleine Staarman. G.H.J. and Richter C.J.J. 1982. Effects of human chorionic gonadotropin (HCG) on maturation and ovulation of oocytes in the ovary of the african catfish. Clarias lazera (C \& V). In Richter C.J.J.. Goos H.J.Th. (editors). Proceedings of International Symposium on Reproduction Physiology of Fish. Pudoc. Wageningen. The Netherlands. 195pp.

Egwui. P.C., 1986. Yields of the african catfish. Clarias gariepinus (Burchell) from a low input homestead concrete pond. Aquaculture, 55, 87-91.

Espinach, Ros. A., Amutio, V.G.. Mestre Arceredillo J.P., Orti, G. and Nani. A. 1984. Induced breeding of the South American catfish. Rhamdia sapo (C \& V). Aquaculiure. 37. 141-146.

Goetz. F.W.. 1983. Hormonal control of oocyte final maturation and ovulation in fishes. In: Hoar, W.S.. Randall, D.J. and Donaldson, E.M. (editors). Fish Physiology, $9 B$, Reproduction. Academic Press, pp. 117-170.

Goos, H.J.Th.. de Leeuw. R.. Burzawa-Gérard. E.. Terlou M. and Richter C.J.J., 1986. Purification of gonadotropic hormone from the pituitary of the african catfish. Clarias gariepinus (Burchell) and the development of homologous radiolmmuno assay. Gen. Comp. Endocrinol., 63, 162-170.

Goos, H.J.Th., Joy K.P., de Leeuw, R.. van Oordt. P.G.W.J. van Delft. A.M.L. and Gielen J.Th., 1987. The effect of luteinizing hormone-releasing hormone analogue (LHRHa) in combination with different drugs with anti-dopamine and anti-serotonin properties on gonadotropin release and ovulation in the african catfish Clarias gariepinus. Aquaculture. 63. 143-156.

Goos, H.J.Th. and Richter, C.J.J.. 1996. Internal and external factors controllingreproduction in the African catfish, Clarias gariepinus. In: Legendre $\mathrm{M}$ and Proteau J-P (editors). The biology and culture of catfishes. Aquatic Living Resources, Paris, Vol 9 Hors Séries, pp. 4558.

Haylor, G.S. 1992. Some aspects of the biology and culture of the african catfish, Clarias gariepinus with particular reference to developing African countries. In: Roberts R.J. and Muir J.F. (editors). Recent Advances in Aquaculture Vol. IV. Blackwell Scientific Publications, Oxford. pp. 21-48.

Haylor, G.S., 1993. Controlled hatchery production of african catfish, Clarias gariepinus (Burchell): an overview. Aquac. Fish. Manag. 24. 245-252.

Haylor, G.S. and Mollah, M.F.A., 1995. Controlled hatchery production of african catfish Clarias gariepinus: the influence of temperature on early development. Aquatic Living Resour. 8, 431-438.

Hecht, T., and Lublinkhof, W., 1985. Clarias gariepinus $\mathrm{x}$ Heterobranchus longifilis (Clariidae: Pisces): a new hybrid for aquaculture. South Afri. J. S., 81, 620-621.

Hecht, T., Saayman J.E. and Polling L., 1982. Further observation on the induced spawning of the sharptooth catfish Clarias gariepinus (Clariidae: Pisces). Water S. A. 8, 101-107.
Hetch, T., Uys, W. and Britz, P.J., 1988. The culture of sharptooth catfish, Clariasgariepinus in Southern Africa. South Afr. Nat. Sci. Progr. Rep. 153, 133pp.

Hetch, T., Oellermann, L. and Verheust, L., 1996. Perspectives and clariid catfish culture in Africa. In: Legendre, $M$. and Proteau, J-P. (eds). The Biology and Culture of Calfishes. Aquatic Living Resour. Paris. 1996, vol. 9, Hors Série. pp. 197-206.

Hogendoorn, H.. 1977. Progress in the controlled propagation of Clarias lazera (C\&V). Actes de Collogues du CNEXO. $4.123-130$.

Hogendoorn, H., 1979. Controlled propagation of the african catfish Clarias lazera. Reproductive biology and field experiments. Aquaculture, 17, 323-333.

Hogendoorn. H. and Vismans. M.M. 1980. Controlled propagation of the african catfish. Clarias lazera (C \& V). II: Artificial reproduction. Aquaculture 21.3953.

Horvath. L. and Tamas. G., 1976. The reproduction of the sheat fish (Silurus glanis L.) and raising of the sheat fish forced fry. Halasz. Tudom. Marllek. 2, 11-13.

Jalabert, B., 1976. In vitro oocyte maturation and ovulation in rainbow trout (Salmo gairdneri), northern pike (Esox lucius), and gold fish (Carassius auratus). J. Fish. Res. Bd. Can. 33, 974-988.

Koide. Y.. Noso, T., Schouten, G., Peutre, J., Zandbergen. M.A., Bogerd. J.. Schulz, R.W.. Kawauchi, H. and Goos, H.J.Th.. 1992. Maturationtal gonadotropin from the african catfish, Clarias gariepinus: Purification, characterization, localization and biological activity. Gen. Comp. Endocrinol. 87, 327-341.

Legendre. M.. 1986. Seasonal changes in sexual maturity and fecundity. and HCG-induced breeding of the catfish Heterobranchus longifilis Val. (Clariidae) reared in Ebrién lagoon (lvory Coast). Aquaculture 55, 201 213.

Legendre. M. and Teugels. G.G., 1991. Développement et tolérance a la temperature des oeufs de Heterobranchus longifilis, et comparaison de développments larvaires de $H$. longifilis et de Clarias gariepinus. Aquatic Living Resour: 4, 227-240.

Legendre, M. and Otémé, Z.J., 1995. Effect of varying latency period on the quantity and quality of ova after hCGinduced ovulation in the african catfish Heterobranchus longifilis (Teleostei; Clariidae). Aquatic Living Resour. 8, 309-316.

Legendre, M., Teugels. G. G. Cauty, C. and Jalabert, B., 1992. A comparative study on morphology, growth rate and reproduction of Clarias gariepinus. Heterobranchus longifilis and their reciprocal hybrids (Pisces: Clariidae). J. Fish. Biol., 40. 59-79.

Legendre. M.. Linhart. O.. Billard, R.. 1996. Spawning and management of gametes, fertilized eggs, and embryos in Siluroidei. In: Legendre, M. and Proteau, J-P. (editors). The Biology and Culture of Calfishes. Aquatic Living Resour., Paris 1996, Vol. 9. Hors Série, pp. $59-80$.

Micha. J.C.. 1976. Synthése des essais de reproduction, d'alevinage et de productionchez un silure Africain: Clarias lazera Val. In: Symposium on Aquaculture in Africa. CIFA Technical Paper 4, Supplement 1, pp. 450-473.

Mollah, M.F.A. and Tan, E.S.P., 1982. Effects of incubation temperature on the hatching of the catfish (Clarias macrocephalus Gunther) egg with an illustration on the larval stages. Malay. Nature J., 36, 123-131.

Mollah, M.F.A. and Tan, E.S.P., 1983. Viability of catfish (Klarias macrocephalusGunther) eggs fertilized at 
varying post-ovulation times. J. Fish Biol. 22, 563566.

Nozaki, M., Naito, N., Swanson, P., Dickhoff, W.W., Nakai, Y., Suzuki, K., Kawauchi, H., 1990. Salmonid pituitary gonadotrophs. 2. Ontogeny of GTH-I and GTH-II Cells in the rainbow trout, Salmo gairdneri irideus. Gen. Comp. Endocrinol., 77, 358-367.

Nwadukwe, F.O.. Ayinla, O.A. and Abby-Kalio. N.J., 1983. Effects of various doses ofacetone-dried powdered carp pituitary extract and season on hatchery propagation of Heterobranchus longifilis (Val. 1840) (Pisces: Clariidae). J. Aquac. in Trop. 8, 33-40.

Pham, A. and Raugel, B., 1977. Contribution à l'étude de la reproduction provoquee des femelle de Clarias lazera (Val.) (Pisces: Clariidae). CTFT, Nogent-sur-Marne. $15,27-33$

Peute, J., de Leeuw, R., Goos, H.J.Th. and van Oordt, P.G.W.J., 1984. Ultrastructrure of the gonadotropes and immunolabelling of gonadotropes and thyrotrops in the pituitary of the African catfish, Clarias lazera. Cell Tissue Res. 238, 95-103.

Peute, J., Zandbergen, M.A., Goos, H.J.Th. and van Oordt P.G.W.J., 1986. Pituitarygonadotropin contents and ultrastructure of the gonadotropes in the African catfish Clarias gariepinus during the annual cycle in a natural habitat. Can. J. of Zool., 64, 1718-1726.

Resink, J.W., Schoonen, W.G.E.J., van den Hurk, R.R., Viveen. W.J.A.R. and Lambert, J.G., 1987. Seasonal changes in stereoid metabolism in the male reproductive organsystem of the African catfish Clarias gariepinus. Aquaculture, 63, 59-76.

Resink, J.W., Schoonen, W.G.E.J., Albers, P.C.H., Filé, D.M., Notenboom. C.D., van den Hurk, R. and van Oordt, P.GW.J., 1989a. The chemical nature of sex attracting pheromones from the seminal vescile of the African catfish Clarias gariepinus. Aquaculture 83. 137-151.

Resink, J.W., van den Berg, T.W.M., van den Hurk. R.R., Huisman, E.A. and van Oordt, P.G.W.J., 1989. Induction of gonadotropin release and ovulation by pheromones in the African catfish Clarias gariepinus. Aquaculture 83, 163-177.

Richter, C.J.J., 1976. The african catfish, Clarias lazera. A new possibility for fishculture in tropical regions? In: Huisman E.A. (editor), Aspecls of Fish Culture and Fish Breeding. Miscellaneous Paper No. 13. Landbouwhogeschool, Wageningen. pp. 5I-72

Richter, C.J.J., van den Hurk, R., 1982. Effects of 11-desoxycortico sterone-acetate and carp pituitary suspension fallicule maturation in the ovaries of the African catfish, Clarias lazera (C. \& V.) Aquaculture, 29, 53-66

Richter, C.J.J., Eding, E.H., Leuven, S.E.W. and van der Wijst. J.G.M., 1982. Effects of feeding levels and temperature on the development of the gonad in the african catfish Clarias lazera (C. \& V.) In: Richter, C.J.J. and Goos, H.J.Th. (editors). Proceedings of Symposium on Reproductive Physiology of Fish PUDOC, Wageningen, pp. 147-150.

Richter, C.J.J., Eding, E.H. and Roem, A.J., 1985. 17 $\alpha-$ hydroxyprogesterone-induced breeding of the African catfish, Clarias gariepinus (Burchell), without priming with gonadotropin. Aquaculture 44, 285-293.

Richter, C.J.J., Eding, E.A., Goos, H.J.Th., de Leeuw, R., Scott, A.P. and van Oordt, P.G.W.J., 1987a. The effect of pimozide/LHRHa and $17 \alpha$-hydrogesterone on plasma steroid levels and ovulation in the African catfish, Clarias gariepinus Aquaculture 63, 157-168.

Richter, C.J.J., Viveen, W.J.A.R., Edinh, E.H., Sukkel, M., Rothuis, A.J., van Hoof, M.F.P.M., van den Berg,
F.G.J. and van Oordt, P.G.W.J., 1987b. The significance of photoperiodicity, water temperature and inherent endogenous rhythm for the production of viable eggs by the African catfish, Clarias. gariepinus. kept in subtropical ponds in Israel and under Israel and Dutch hatchery conditions. Aquaculture 63, 169-185.

Shoonbee, H.J., Hetch, T., Polling, L. and Saayman, J.E., 1980. Induced spawning of and hatchery procedures with the sharptooth catfish. Clarias gariepinus (Pisces: Clariidae). South Afr. J. of Sci. 76, 364-367.

Schoonen, W.G.E.J. and Lambert, J.G.D., 1986. Steroid metabolism in the testes of the African catfish, Clarias gariepinus (Burchell), during the spawning season, under natural conditions and kept in ponds. Gen. Comp. Endocrinol. 61, 355-367.

Schoonen, W.G.E.J., Granneman, J.C.M., Lambert, J.G.D. and van Oordt, P.G.W.J., 1987a. Steroidogenesis in the testes and seminal vesicles of spawning and nonspawning Africa catfish, Clarias gariepinus. Aquaculture 63, 77-88.

Schoonen, W.G.E.J., Grannemann, J.C.M., Lambert, J.G.D., Viveen, W.J.A.R. and van Oordt, P.G.W.J., $1987 \mathrm{~b}$. Quantitative studies of steroid bioconversion in the seminal vescicles of spawning male african catfish, Clarias gariepinus (Burchell) under natural and fish farm conditions. Comp. Biochem. and Physiol., 87B, 687-695.

Schoonen, W.G.E.J., Lambert, J.G.D., Resink, J.W., Viveen, W.J.A.R. and van Oordt, P.G.W.J., 1987c. A quantitative study of steroid conversion in the testes of African catfish, Clarias gariepinus (Burchell), under natural spawning and natural and culture nonspawning conditions. $J$. of Endocrinol. 112, 323-332.

Stacey, N.E., Kyle, A.L. and Liley, N.R., 1986. Fish reproductive pheromones. In: Durval. D.. Muller-Schwarze, D. and Silverstein, R.M. (eds). Chemical Signals in Vertebrates. Vol IV. Plenum Press, New York, pp. 117-133.

Sydenham, D.H.J., 1980. New species of Clarias from West Africa. Rev. Zool. Afr., Vol. XCIV, Fasc., 31, 659-677.

Sydenham, D.H.J., 1981. New species of Clarias from Nigeria (Pisces: Clariidae). Rev. Zool. Afr., Vol. XCV, Fasc. I, 234-241.

Teugels. G.G. 1986a. Clariidae, In: Daget, J., Gosse, J-P., Thys van den Audenaerde. D.F.E. (editors). Check-list of the Freshwater fishes of Africa. ISNB, Brussels, MRAC, Tervuren, ORSTOM, Paris, pp. 66-101

Teugels, G.G. 1986b. A systematic revision of the African species of the genus Clarias (Pisces; Clariidae). Ann. Mus. R. Afr. Contr. 247, 1-199.

Teugels, G.G., 1996. Taxonomy, phylogeny and biogeography of catfishes (Ostariophysi; Siluroidei): an overview. In: Legendre, M. and Proteau, J-P. (eds). The Biology and Culture of Catfishes. Aquatic Living Resources, Vol. 9, Hors Série Paris, pp. 9-34.

van Asselt, L.A.C., Goos, H.J.Th., van Dijk, W. and Brass, J., 1989. Role of calcium ion in action of gonadotropin releasing hormone on gonadotropin secretion in the african catfish, Clarias gariepinus. Gen. Comp. Endocrinol. 76, 46-52.

van den Hurk, R., Viveen, W.J.A.R., Pinkas, R. and van Oordt, P.G.W.J.. 1985. The natural gonadal cycle in the African catfish, Clarias gariepinus: a basis for applied studies on its reproduction in fish farms. Israeli J. Zool. 33, 129-147.

van der Waal, B.C.W., 1974. Observations on the breeding habits of Clarias gariepinus (Burchell). J. Fish. Biol. 6, 23. 27.

van der Waal, B.C.W., 1985. Stripping male Clarias gariepinus standard. Aquaculture 48, 137-142. 